\title{
Male Penile Urethra and Female Urethra Cancer pTa TNM Finding v8
}

National Cancer Institute

\section{Source}

National Cancer Institute. Male Penile Urethra and Female Urethra Cancer pTa TNM

Finding v8. NCI Thesaurus. Code C140440.

Urethral cancer with a finding of non-invasive papillary carcinoma. (from AJCC 8th Ed.) 